\title{
EFFECTS OF ENVIRONMENTAL HETEROGENEITY ON THE COMPOSITION OF INSECT TROPHIC GUILDS
}

\author{
OLIVIER, R.S. ${ }^{* 1}-$ ARANDA, R. ${ }^{2}-$ GODOI, M.N. ${ }^{2}-$ GRACIOLLI, G. ${ }^{1}$ \\ ${ }^{1}$ Laboratório de Zoologia, Centro de Ciências Biológicas e da Saúde, Universidade Federal de \\ Mato Grosso do Sul \\ UFMS, CEP 79090-900, Campo Grande, Mato Grosso do Sul, Brasil.ggraciolli@hotmail.com \\ (phone: +55(67)3345733) \\ ${ }^{2}$ Programa de Pós-graduação em Ecologia e Conservação, Universidade Federal de Mato \\ Grosso do Sul \\ UFMS, CEP 79090-900, Campo Grande, Mato Grosso do Sul, Brasil. \\ rodrigoaranda.biologo@gmail.com; mauricioecologia@hotmail.com \\ (phone: +55(67)33457342) \\ *Corresponding author \\ e-mail: renanolivier91@gmail.com
}

(Received $27^{\text {th }}$ Aug 2013 ; accepted $22^{\text {nd }}$ July 2014)

\begin{abstract}
Distribution of the most diverse groups of insects is highly related to the structural complexity of the plant community, and increasing complexity, in turn, correlates with increasing diversity, richness and abundance of insects. As such, this study aims to examine the relationship between environmental heterogeneity and the richness, abundance and trophic guilds of insects. The study was conducted in the Serra da Bodoquena, Mato Grosso do Sul, Brazil. Samples were collected using an entomological net, and analysis of the distribution of functional groups along the environmental gradient was performed by direct ordering. The richness and abundance of insect species differ among the different vegetation types, such as clean pasture or cerrado. Using a functional Heterogeneity Index (HI), generalist groups showed a wide distribution, while more specialized groups were restricted to more structurally complex environments.

Keywords: structural complexity, environmental gradient, functional groups
\end{abstract}

\section{Introduction}

The correlation between species diversity and environmental heterogeneity may vary according to the species group and can depend on both biotic and abiotic factors, according to the group being studied (Tews et al., 2004). However, distribution of the most diverse groups of insects is highly related to the structural complexity of vegetation, and, generally, the richness, diversity and abundance of insects increase as environmental heterogeneity increases. This was verified in Coleoptera (Halffter and Arellano, 2002; Almeida and Louzada, 2009; Janssen et al., 2009), Hymenoptera (Fonseca and Diehl, 2004) and Orthoptera (Azevedo et al., 2011).

Through environmental heterogeneity, studies have shown that disturbances in vegetation structure resulting from human or animal activity are harmful to insect fauna and cause a reduction in both diversity and abundance (Fonseca and Diehl, 2004; Vasconcellos et al., 2010). In addition, replacing native vegetation with exotic species, often montypic, e.g., areas with Pinus spp., can directly interfere with the richness and abundance of insects (Romero-Alcaraz and Ávila, 2000; Ganho and Marinoni, 2006; Almeida et al., 2011).

Heterogeneity also directly influences the availability of resources and favorable conditions for soil organisms (Warren and Zou, 2002). For example, Orthoptera 
(Gryllidae) has increased its richness in more closed, i.e., heterogeneous environments because these sites have high humidity and a high quantity of litter and organic matter (Azevedo et al., 2011).

Forest structure has been identified as a key determinant of biodiversity (Spies, 1998). Schäffers et al. (2008), through predictive analysis of co-correlation and comparisons between the composition of arthropods and plant species, demonstrated that flora is the most effective indicator of arthropod composition. Therefore, using several variables, many researchers have recently employed a heterogeneity index, or HI, to represent such composition, e.g., Morato (2004), McElhinny et al. (2006) and Janssen et al. (2009).

The relationship between species and environment can be analyzed in several ways, in particular by the formation of guilds. Guilds, as defined by Root (1967), consist of a group of species that exploit the same class of environmental resources and with similar patterns of exploitation. Using this concept, the guild becomes an interesting unit for both research related to interspecific interactions and analysis of communities, since it is a functional unit, making it unnecessary to consider each species as a separate entity (Odum, 1985; Fauth et al., 1996).

The present study aimed to determine the effects of environmental heterogeneity on species richness, abundance and trophic guilds of insects. Furthermore, the study is based on the hypothesis that increasing environmental heterogeneity results in greater richness, abundance and frequency of occurrence of trophic guilds.

\section{Materials and Methods}

\section{Study Area}

The study was conducted at Estancia Mimosa Ecotourism (EME) (20 58'57.70"S and $56^{\circ} 30^{\prime} 58.40^{\prime \prime} \mathrm{W}$ ), about 400 hectares within the municipality of Bonito, Mato Grosso do Sul. The southernmost boundary of the farm is the Mimoso River, which constitutes about 15-20 km of the National Park of Bodoquena Range (PNSB) (Fig. 1).

The Bodoquena Range is underlain by limestone rocks, Corumbá Group (Neoproterozoic III), with altitudes ranging from 450 to $650 \mathrm{~m}$, mostly devoid of soil development. The rocky substrate is covered by one of the last remnants of vegetation of the plateau and is characterized by the predominance of seasonal deciduous and semi-deciduous forest (Boggiani et al., 1999). Savanna and gallery forest physiognomies are also found (Faria and Araújo, 2010).

\section{Sampling}

Samples were collected between September 2011 and June 2012 in 164 randomized samples units $\left(5\right.$ subplots $16 \mathrm{~m}^{2}$ ) totaling $80 \mathrm{~m}^{2}$ each and spaced at least $200 \mathrm{~m}$ apart to avoid possible overlap between the samples. These units were distributed in six distinct physiognomies sampled according to their representation in the study area (Table 1).

The collection method used was an insect net adapted from Waquil (1997). From 15 to 20 plots were sampled monthly in the morning between 8:00 and 10:00 A.M. In each sampling unit, insects' understory was captured with a handnet, and a sampling time of ten minutes per plot was maintained. The captured insects were placed in Falcon tubes containing $70 \%$ alcohol, properly labeled, and taken to the Laboratory of Zoology at the Universidade Federal de Mato Grosso do Sul for triage and identification of specimens. 


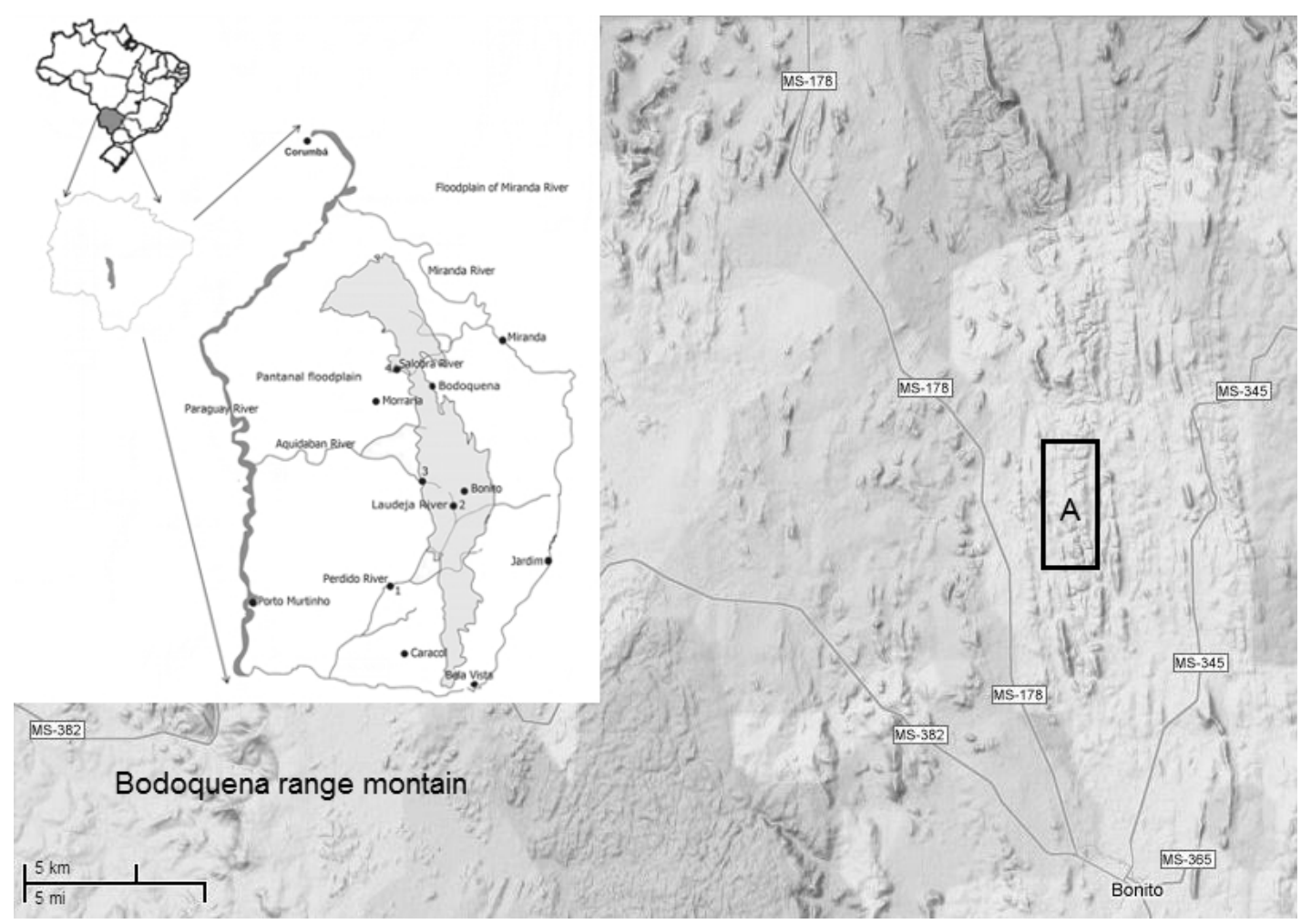

Figure 1. Location of Bodoquena Mountains and Estância Mimosa Ecoturismo (A) in the municipality of Bonito, Mato Grosso do Sul, Brazil. Adapted from Dalzochio et al. (2011).

Table 1. Description of vegetation types found in the study area of Bodoquena Mountains, State of Mato Grosso do Sul. Number of samples in each vegetation type (n). Adapted from Ribeiro and Walter (1998); Cirelli and Penteado-Dias (2003).

\begin{tabular}{|c|c|}
\hline Phytophysiognomy & Description \\
\hline Seasonal Forest (44) & $\begin{array}{l}\text { Predominance of large woody individuals, } 10 \text { to } 25 \text { meters, with } \\
\text { a dense canopy and understory continuous and well developed. }\end{array}$ \\
\hline Riparian Forest (9) & $\begin{array}{l}\text { Forest vegetation accompanying rivers of medium and large size } \\
\text { of the Cerrado region, where woody vegetation does not form } \\
\text { galleries. Overall, this forest is relatively narrow, rarely } \\
\text { exceeding } 100 \text { meters in width on each side. This formation } \\
\text { commonly occurs on rough terrain and may not always be an } \\
\text { obvious transition to other forest formations, such as the dry } \\
\text { forest and the Cerradão. }\end{array}$ \\
\hline Cerradão (14) & $\begin{array}{l}\text { Forest formation with xeromorphic aspect. Characterized by the } \\
\text { presence of species that occur in the Cerrado and also by wood } \\
\text { species. While it is a forest, it is more floristically similar to the } \\
\text { Cerrado. It predominantly provides a continuous canopy and } \\
\text { tree cover which can oscillate } 50 \text { to } 90 \% \text {. The average height of } \\
\text { the tree stratum varies from } 8 \text { to } 15 \text { meters, providing light } \\
\text { conditions that favor the formation of differentiated shrub and } \\
\text { herbaceous plants. Epiphytes are reduced. }\end{array}$ \\
\hline Cerrado sensu stricto (34) & $\begin{array}{l}\text { Characterized by the presence of low, very rigid trees with such } \\
\text { characteristics as sloping and winding, with branches twisted } \\
\text { and irregular, often with evidence of burnt leaves. Subshrubs } \\
\text { and shrubs are scattered, with some species presenting }\end{array}$ \\
\hline
\end{tabular}


underground organs of resistance (xylopodes), allowing regrowth. In the rainy season, shrubs and herbaceous plants grow rapidly. Woody species in general have trunks with thick cork, chipped or grooved, and apical buds of many species are protected by dense hairiness.

Dirty pastures (28) Brachiaria pastures and other exotic grasses with high coverage of bushes and trees.

Clean pastures (35) Brachiaria pastures and other exotic grasses with low coverage of bushes and trees.

All insects were morphotyped and subsequently identified up to the family level. Identification keys used were based on Costa et al. (2006), Triplehorn and Johnson (2011) and Raphael et al. (2012). To classify insects, feeding guilds were based on Price et al. (1987), Buzzi (2003), Triplehorn and Johnson (2011), and Rafael et al. (2012) (Table 2). The identified specimens were deposited in the Zoological Collection of the Universidade Federal de Mato Grosso do Sul (ZUFMS).

Table 2. Definitions of guilds presented in the study and their references.

\begin{tabular}{|c|c|c|}
\hline Trophic Guild & Definition & Reference \\
\hline Herbivorous & Feed on solid plant tissue. & Triplehorn and Jonnson (2011) \\
\hline Phytophagous & Feed on living liquid tissues of plants. & Rafael et al. (2012) \\
\hline Nectarivorous & $\begin{array}{l}\text { Feed on nectar, such as bees, butterflies and } \\
\text { some flies. }\end{array}$ & Buzzi (2003) \\
\hline Polyphagous & Feed on pollen. & Rafael et al. (2012) \\
\hline Gall $^{1}$ & $\begin{array}{l}\text { Induce changes in plant tissue in order to } \\
\text { protect and feed their larvae. }\end{array}$ & Price et al. (1987) \\
\hline Predator & $\begin{array}{l}\text { Attack and eat other animals, usually small } \\
\text { animals or those less fit. }\end{array}$ & Triplehorn and Jonnson (2011) \\
\hline Hematophagous $^{2}$ & Feed on blood. & Rafael et al. (2012) \\
\hline Parasitoid & $\begin{array}{l}\text { In their larval stage, feed on other animal } \\
\text { tissues for a relatively long time. The host } \\
\text { usually dies at the end. }\end{array}$ & Rafael et al. (2012) \\
\hline $\begin{array}{l}\text { Detritivore; } \\
\text { Saprophagous }\end{array}$ & $\begin{array}{l}\text { Feed on plant waste, dead trees, or dead } \\
\text { animals, such as carcasses and dung. }\end{array}$ & Triplehorn and Jonnson (2011) \\
\hline Mycetophagous & Feed on fungi. & Rafael et al. (2012) \\
\hline Omnivorous & Feed on both animals and plants. & Buzzi (2003) \\
\hline
\end{tabular}

To obtain environmental variables, each plot was divided into five sub-plots, one being central with four cardinal positions (north, south, east and west) spaced at least ten meters apart. Each subplot was $16 \mathrm{~m}^{2}$, and the following variables were recorded: number of trees $(\mathrm{dbh} \geq 10 \mathrm{~cm})$, number of dead trees, number of shrubs $(\mathrm{dbh}<10 \mathrm{~cm})$, canopy height $(\mathrm{m})$, canopy cover $(\%)$, herbaceous plant height $(\mathrm{cm})$, herbaceous plant cover $(\%)$, and litter cover $(\%)$, obtaining an average for each point. 


\section{Data Analysis}

Descriptive analyses were emphasized, including communities and their taxonomic levels, number of families, number of trophic guilds and their respective percentages. For each plot sampled, the richness and abundance of insects, as well as the composition of trophic guilds, were noted. For eusocial insects, the abundance not was considered, just the frequency in the samples.

To detect differences between richness and abundance of insects between the environments, Analysis of variance (ANOVA) and the Kruskal-Wallis test were used, as well as non-metric Multidimensional Scaling (NMDS) for the composition of the community.

Principal Component Analysis (PCA) was used to rescue the chageover in relation to the structural complexity of assessing the applicability of the functional Heterogeneity Index.

A functional Heterogeneity Index (HI), as modified by Morato (2004), was generated from the sampled environmental data sampled. The environmental data were standardized, and the frequency of each variable was calculated for each plot. Finally, we calculated the sum of all frequencies per plot, thus giving weight to the magnitude of the variables in each plot, resulting in the following equation:

$$
H I=\sum_{f_{i}}^{n}
$$

where $n=$ number of variables, $f=$ frequency of the variable and $i=$ variable.

With this HI, no loss of variation of the sampled data occurs, since it regains the average values of distribution, and thus, any variation in vegetation structure is rescued. With the values of $\mathrm{HI}$, a simple regression analysis was performed to relate this index to the richness and abundance of insects. An analysis based on the observation of the distribution of trophic guilds along the environmental gradient was performed by direct ordering using $\mathrm{HI}$ as the gradient.

\section{Results}

A total of 1,177 insects were collected. They were distributed among 109 families and 16 orders, of which the most representative were Orthoptera (303), Hemiptera (288), Hymenoptera (237) and Coleoptera (190). The most abundant families were Formicidae (201) (Hymenoptera); Acrididae (134) and Tettigoniidae (124) (Orthoptera); Pentatomidae (70) (Hemiptera) and Chrysomelidae (54) (Coleoptera). Of these 109 families, 80 had equal or less than to five individuals.

Differences were only found in 1) richness between the clean pasture and other vegetative formations and 2) abundance between clean pasture and Cerrado. The other formations showed no difference between the two community metrics evaluated (Table $3)$. The guilds with the highest representation were herbivores $(36.97 \%)$, phytophagous species $(20.20 \%)$, omnivores (18.86\%) and predators $(8.51 \%)$, which showed high frequency throughout the sampling period. Of the seven guilds remaining, six were 
more specialized, thus representing $11.40 \%$ of the total. The remaining $4.06 \%$ represents the saprophage guild.

Table 3. Comparison of Richness (gray) and Abundance (white) in relation to forest types (ANOVA $(F)$ or Kruskal-Wallis $(H)$ test).

\begin{tabular}{lccccccccccccc}
\hline & \multicolumn{1}{c}{ Clean Pasture } & \multicolumn{1}{c}{ Dirty } & Pasture & \multicolumn{2}{c}{ Cerrado } & \multicolumn{2}{c}{ Cerradão } & \multicolumn{3}{c}{ Riparian Forest } & \multicolumn{3}{c}{ Seasonal Forest } \\
\hline & $\mathbf{F}$ & $\mathbf{P}$ & $\mathbf{F}$ & $\mathbf{P}$ & $\mathbf{F}$ & $\mathbf{P}$ & $\mathbf{F}$ & $\mathbf{P}$ & $\mathbf{F}$ & $\mathbf{P}$ & $\mathbf{F}$ & $\mathbf{P}$ \\
Clean Pasture & -- & -- & 3.631 & $0.061^{* *}$ & 9.356 & $0.003^{*}$ & 3.591 & $0.065^{* *}$ & 4.204 & $0.048^{*}$ & 6.248 & $0.015^{*}$ \\
Dirty Pasture & $2.109^{\mathrm{k}}$ & $0.034^{\mathrm{k}}$ & -- & -- & 0.934 & 0.337 & 0.00202 & 0.964 & 0.351 & 0.557 & 0.0476 & 0.828 \\
Cerrado & 3.804 & $0.05^{*}$ & $0.32^{\mathrm{k}}$ & $0.572^{\mathrm{k}}$ & -- & -- & 0.692 & 0.41 & 0.000027 & 0.996 & 0.834 & 0.364 \\
Cerradão & $0.972^{\mathrm{k}}$ & $0.324^{\mathrm{k}}$ & $1.388^{\mathrm{k}}$ & $0.239^{\mathrm{k}}$ & 1.568 & 0.217 & -- & -- & 0.461 & 0.504 & 0.0197 & 0.889 \\
Riparian Forest & 1.137 & 0.294 & $0.218^{\mathrm{k}}$ & $0.641^{\mathrm{k}}$ & $0.05^{*}$ & 0.816 & 0.694 & 0.414 & -- & -- & 0.331 & 0.567 \\
Seasonal Forest & 1.974 & 0.164 & $1.061^{\mathrm{k}}$ & $0.303^{\mathrm{k}}$ & 0.828 & 0.366 & 0.422 & 0.519 & 0.112 & 0.739 & -- & -- \\
\hline
\end{tabular}

* significant difference $(\mathrm{P}=0.05)$

** significant difference $(P=0.1)$

k=Kruskal-Wallis test

When $\mathrm{HI}$ is related to the six vegetation types generated by the grouping of structurally similar environments, we note that three groups were formed, with the corresponding changes in HI, even with large overlap of values: low heterogeneity (clean pasture $(\mathrm{HI}=0.025 \pm 0.009)$ and dirty pasture $(\mathrm{HI}=0.043 \pm 0.013)$ ), intermediate heterogeneity (Cerrado sensu stricto $(\mathrm{HI}=0.050 \pm 0.014)$ and Cerradão $(\mathrm{HI}=0.051 \pm 0.011)$ ), and high heterogeneity (riparian forest $(\mathrm{HI}=0.071 \pm 0.018)$ and lowland forest $(\mathrm{HI}=0.063 \pm 0.017)$ ). Only two types of vegetation showed no overlapping HI values, indicating structural complexities at two extremes, i.e., clean pasture $v s$. riparian forest (Fig. 2). In regression analysis, no significant relationship was observed between $\mathrm{HI}$ and either the number of species or abundance of insects $(\mathrm{P}>0.05)$ (Fig. 3). Comparing the structure of insect community (NMDS) in relation to environmental variables by PCA, it was found that only $18 \%$ of community structure is explained by environmental factors (Fig. 4).

In direct ordering analysis (Fig. 5), there was a low proportion of groups in relation to increased $\mathrm{IH}$. Frequencies of only the most highly specialized groups, such as parasitoids, hematophagous species and gallers, had increased along with greater values of HI. The four less specialized groups occurred throughout the gradient of heterogeneity. The insects in these groups are largely leaf-hoppers (phytophagous), grasshoppers and beetles (herbivores), praying mantis, lacewings, bug killers (predators), and ants and cockroaches (omnivores).

\section{Discussion}

Areas with less heterogeneity showed lower species richness and abundance of individuals. Other studies have demonstrated this relationship for different groups of insects (Romero-Alcaraz and Ávila, 2000).

Comparing HI and the physiognomies studied, we note the grouping of similarly structured environments. This same model where vegetation types are grouped according to structural complexity, i.e., less complex (fields) to more complex (forests), has been employed in other studies (Almeida and Louzada, 2009; Silva et al., 2010). 


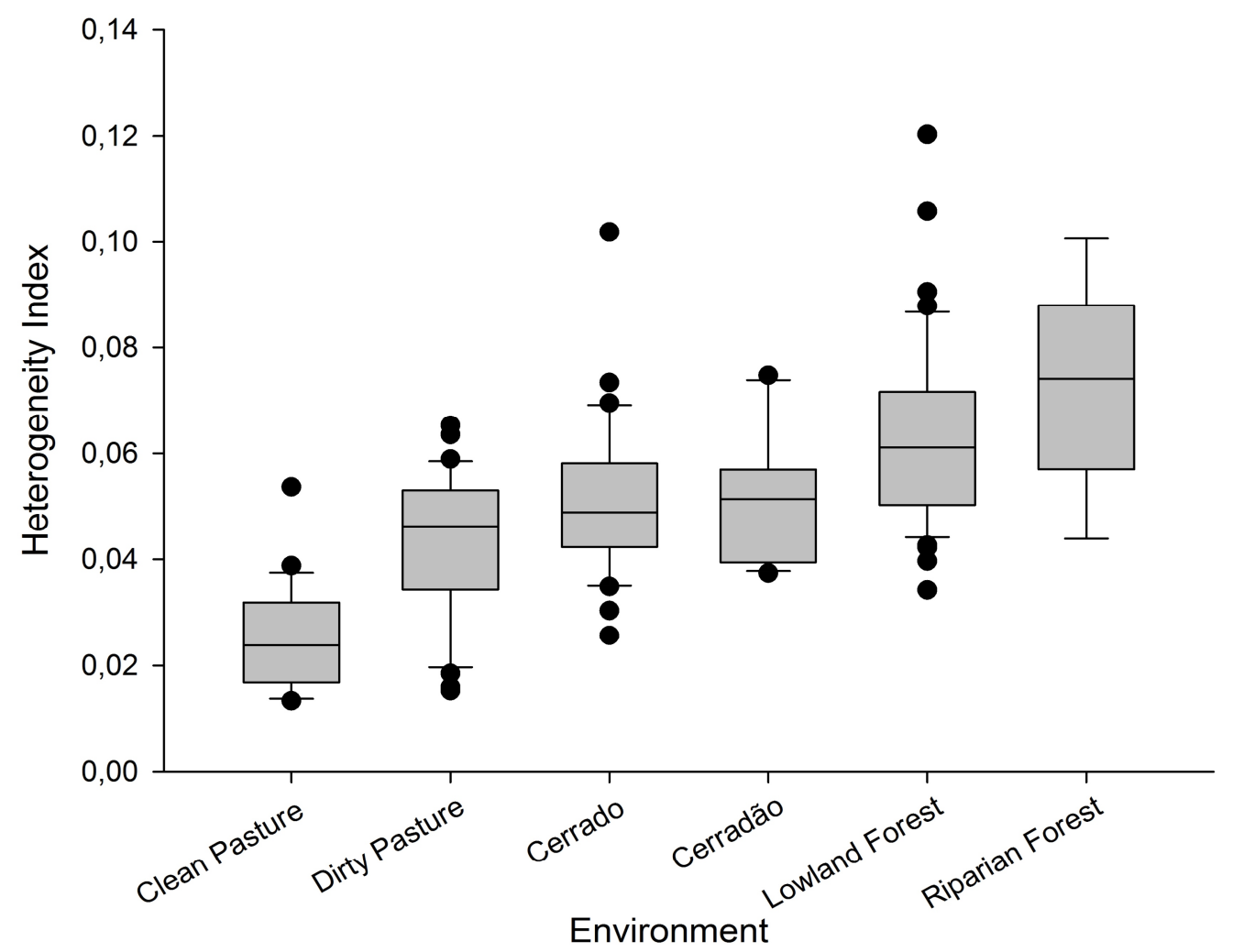

Figure 2. Heterogeneity Index in each of the six vegetation types located in Estancia Mimosa Ecotourism, Bodoquena Mountains, Brazil, from 09/2011 to 06/2012.

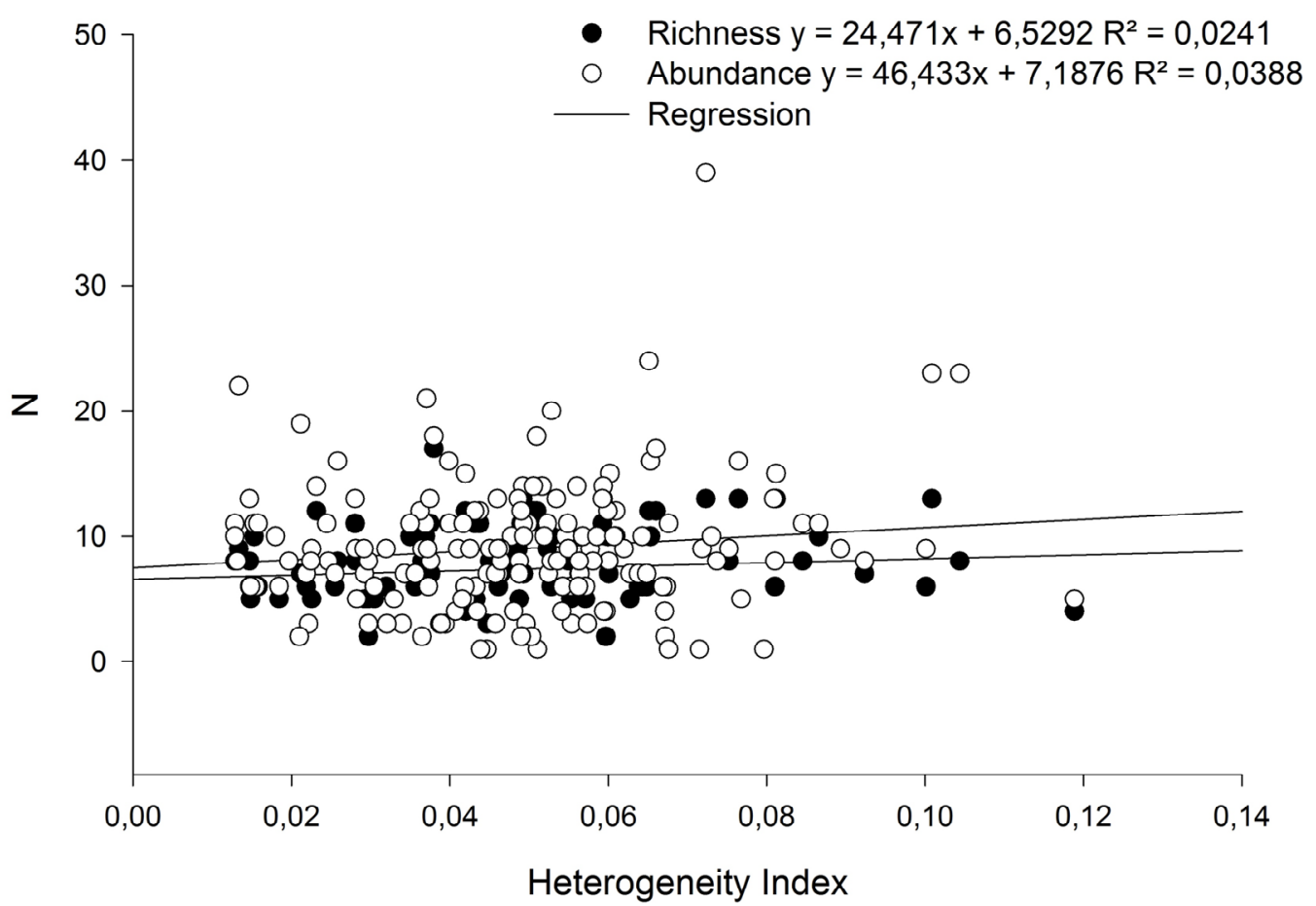

Figure 3. Linear regression between richness and abundance of insects and Heterogeneity Index at Estancia Mimosa Ecotourism, Bodoquena Range Mountains, Brazil from 09/2011 to $06 / 2012$. 


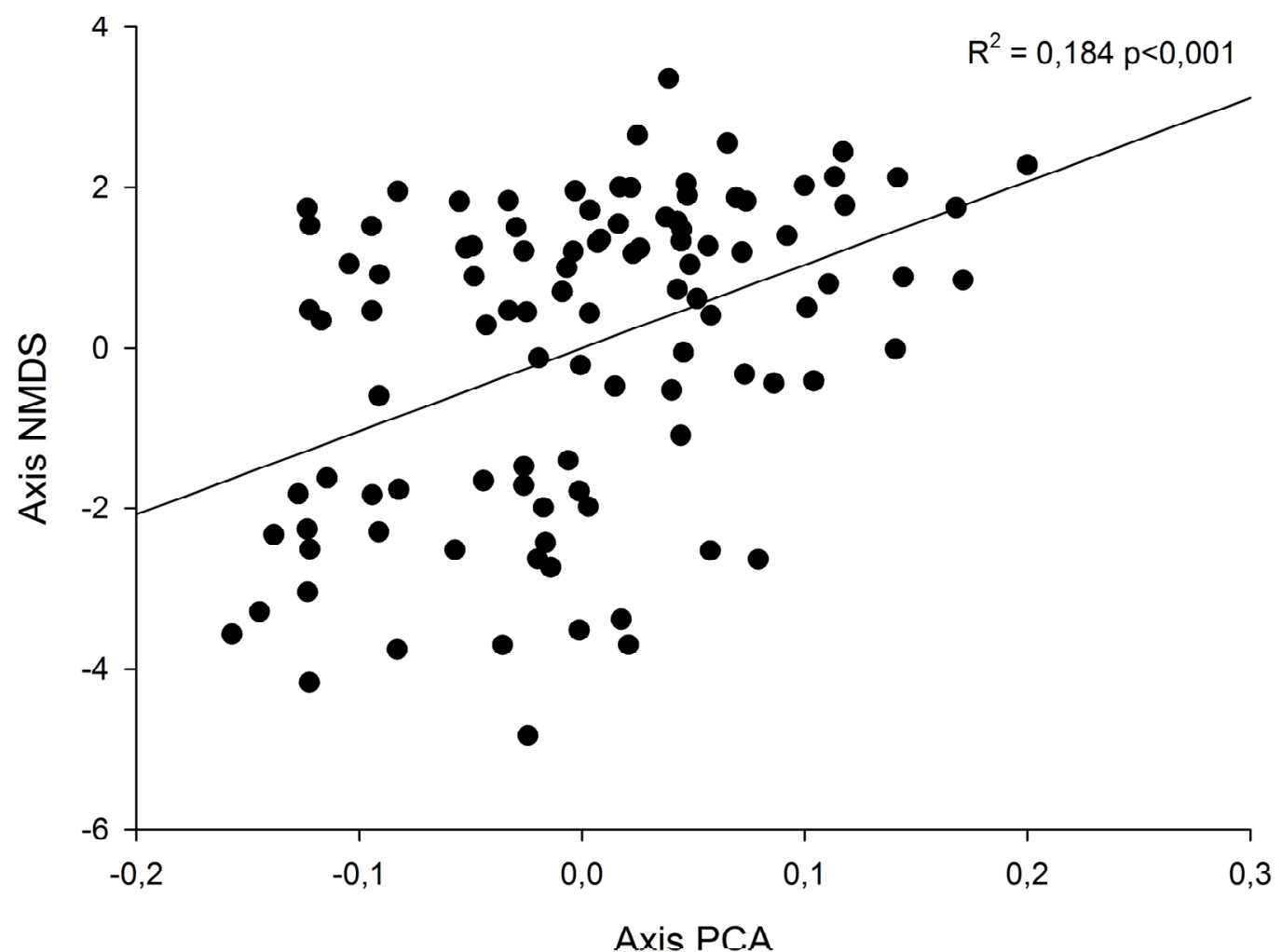

Figure 4. Relationship between insect community (NMDS) and Environmental Variables by $P C A$.

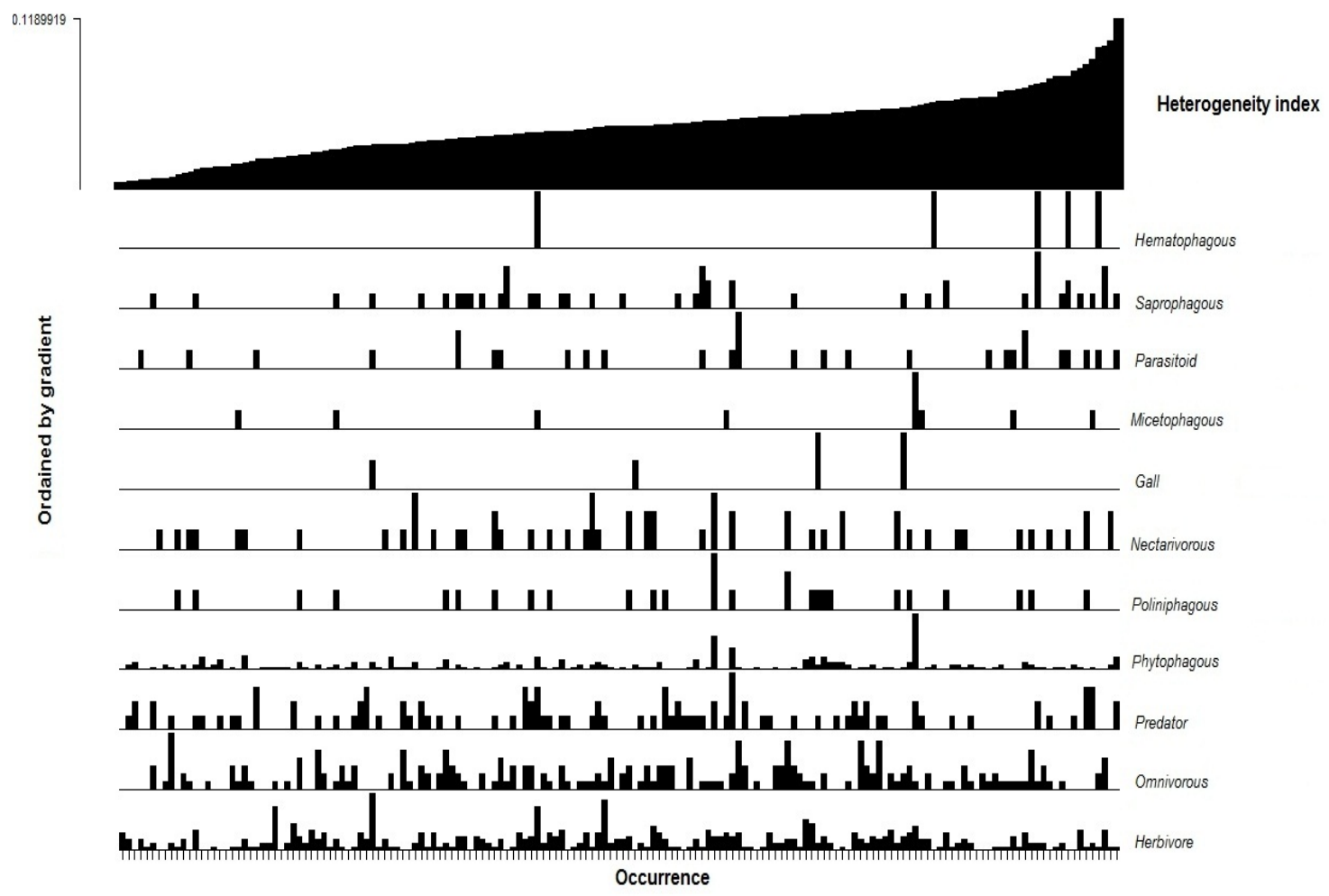

Figure 5. Direct Ordering Analysis of the frequency of trophic guilds in relation to the values of environmental heterogeneity at Estancia Mimosa Ecotourism, Bodoquena Range Mountains, Brazil from 09/2011 to 06/2012. 
Through linear regression analysis, we saw that the HI did not significantly influence the variables of richness and abundance. Similarly, Loyola and Martins (2008), working with solitary wasps and bees, demonstrated that the structural complexity of vegetation was not a predictor of richness and abundance. However, we can still see that a few individuals occupied environments with $\mathrm{HI} \geq 0.08$, a fact that may be related to a high degree of specialization in eating habits, such as representatives of the Culicidae family, where females are hematophagous. Lourenço-de-Oliveira (1984) compared the frequency of Culicidae (Diptera) in different environments. The largest proportion of Culcidae $(63.2 \%)$ was found in secondary forest, most likely because this environment was better preserved and, hence, more heterogeneous with the additional benefit of favorable climatic conditions for these insects when compared to the less heterogeneous, more degraded environments.

The functional composition of the ecosystem can respond more efficiently to the community structure than metrics such as richness and abundance. Neves et al. (2010) show how community composition reflects the successional stages when compared to using only richness.

In the direct ordering analysis, the group of parasitoids had a peak in frequency in an environment with an intermediate level of HI, a phenomenon possibly resulting from the sampling methodology used, i.e., an insect net, when the Malaise trap, as employed by Cirelli and Penteado-Dias (2003) and Azevedo et al. (2006), would have been the ideal technique for capturing insects belonging to this group. This group also showed a gradually increasing frequency distribution, according to environmental heterogeneity, which resulted in a higher frequency in environments with high HI. Similarly, Azevedo et al. (2006), working with Bethylidae fauna (Hymenoptera) and conducting studies of community structure and faunal similarity among eight different localities, proposed that environmental heterogeneity could be an important factor explaining the relative abundance and composition of these parasitoids, since geographical distance is not a factor for this group.

The hematophagous species clearly showed a higher frequency in environments with high HI, thus demonstrating a preference for local and structurally more complex environments that provide a favorable microclimate. This was similar to the result obtained by Marques and Forattinni (2008) who identified a greater abundance of hematophagous insects (Culicidae) in preserved heterogeneous environments (forest), when compared to areas with less heterogeneity and higher degree of disorder, such as found in peri-urban habitats.

Galling insects, such as the Cecidomyiidae (Diptera), were found most frequently in environments with intermediate $\mathrm{HI}$, as represented by Cerrado and cerradão areas. Notably, xeric, hygrothermally-challenged environments were preferred for their nutritional value with typical sclerophyllous vegetation, confirming the results of Fernandes and Price (1991), Fernandes et al. (1995) and Gonçalves-Alvim and Fernandes (2001).

Groups having a direct relationship with the reproductive structures of plants (polyphagous and nectarivorous) occurred in "pulses", during periods when the flowers fulfill different needs of insects, such as mating, feeding and ovi-position (Villiers, 1972). Seasonality can also interfere with this distribution, since the insects commonly exhibit a seasonal pattern of distribution throughout the year (Silva et al., 2011).

With respect to saprophagous species, we obtained gradually increasing frequency from intermediate heterogeneity values. Clearly, this group maintains a close 
relationship with other animals or plants which provide food. Almeida and Louzada (2009) hypothesized that increased heterogeneity would attract a greater number of animals and therefore generate a higher number of detritus in more complex environments. In a complementary way, Hülle (2006) noted that large- and mediumsized mammals prefer areas with moderate complexity, a fact that allows us to understand the presence of insects' decompositor in environments with this characteristic physiognomy.

The four less specialized groups showed similar distribution, low frequency in environments with low HI, high frequency in intermediate levels of $\mathrm{HI}$ and small decline in frequency in environments with high HI. This low frequency in environments with high complexity was also verified by Menezes et al. (2009) who found that the soil macrofauna of forest fragments in the dry season is dominated by social insects, especially ants. Therefore, interspecific competition may be one explanation for this small decline in these locations.

This distribution pattern in which the frequency varies along the gradient, with modest increase in frequency in environments with intermediate values of HI, was also evaluated for Hemiptera and Hymenoptera predators (Uehara-Prado et al., 2010).

Using the gradient of structural complexity of vegetation, as determined through the use of a functional index of heterogeneity, three structurally distinct environments were delineated, while, at the same time, preventing the loss of variation of environmental data. Thus we obtained a gradient that reflects exactly the variation of heterogeneity.

The diversity and abundance of insects showed an unsatisfactory relationship with the HI. The eleven feeding guilds showed different distribution patterns, and only highly specialized feeding guilds showed gradual distribution, with the frequency increasing with increasing structural complexity of vegetation.

Acknowledgements. Estância Mimosa Ecotourism gave full cooperation to the researchers carrying out this study.

\section{REFERENCES}

[1] Almeida, S.S.P., Louzada, J.N.C. (2009): Estrutura da comunidade de Scarabaeinae (Scarabaeidae: Coleoptera) em fitofisionomias do Cerrado e sua importância para a conservação. - Neotropical Entomology 38(1): 32-43.

[2] Almeida, S., Louzada, J., Sperber, C., Barlow, J. (2011): Subtle land-use change and tropical biodiversity: Dung beetles communities in Cerrado grasslands and exotic pastures. - Biotropica 43(6): 704-710.

[3] Azevedo, C.O., Helmer, J.L., Barreto, F.C.C. (2006): Análise da fauna de Bethylidae (Hymenoptera, Chrysidoidea) de oito localidades do Paraná, Brasil. - Boletim do Museu de Biologia Mello Leitão 20: 83-94.

[4] Azevedo, F.R., Moura, M.A.R., Arrais, M.S.B., Nere, D.R. (2011): Composição da entomofauna da Floresta Nacional do Araripe em diferentes vegetações e estações do ano. - Revista Ceres (Viçosa) 5(6): 740-748.

[5] Boggiani, P.C., Coimbra, A.M., Gesicki, A.L., Sial, A.N., Ferreira, V.P., Ribeiro, F.B., Flexor, J.M. (1999): Tufas calcárias da Serra da Bodoquena. - In: Schobbenhaus, C., Campos, D.A., Queiroz, E.T., Winge, M., Berbert-Born, M. (ed.) Sítios Geológicos e Paleontológicos do Brasil, Editora Brasília, Brasília.

[6] Buzzi, Z.J. (2003): Coletânea de termos técnicos de Entomologia. - Editora UFPR, Curitiba. 
[7] Callisto, M., Esteves, F.A. (1998): Categorização funcional dos macroinvertebrados bentônicos em quatro ecossistemas lóticos sob influência das atividades de uma mineração de bauxita na Amazônia Central (Brasil). - Oecologia Brasiliensis 5: 223-234.

[8] Cirelli, K.R.N., Penteado-Dias, A.M. (2003): Análise da riqueza da fauna de Braconidae (Hymenoptera, Ichneumonoidea) em remanescentes naturais da Área de Proteção Ambiental (APA) de Descalvado, SP. - Revista Brasileira de Entomologia 47(1): 89-98.

[9] Costa, C., Ide, S., Simonka, C.E. (2006): Insetos imaturos: Metamorfose e identificação. Editora Holos, Ribeirão Preto.

[10] Dalzochio, M.S., Costa, J.M., Uchôa, M.A. (2011): Diversity of Odonata (Insecta) in lotic systems from Serra da Bodoquena, Mato Grosso do Sul State, Brazil. - Revista Brasileira de Entomologia 55(1): 88-94.

[11] Faria, R.R., Araújo, A.C. (2010): Flowering phenology and pollination of ornithophilous species in two habitats of Serra da Bodoquena, Mato Grosso do Sul, Brazil. Anais da Academia Brasileira de Ciências 82(4): 843-855.

[12] Fernandes, G.W., Price, P.W. (1992): The adaptative significance of insect gall distribution: survivorship of species in xeric and mesic habitats. - Oecologia 90(1): 1420.

[13] Fernandes, G.W., De Paula, A.S., Júnior, R.L. (1995): Distribuição diferencial de insetos galhadores entre habitats e seu possível uso como bioindicadores. - Vida Silvestre Neotropical 4(2): 133-139.

[14] Fonseca, R.C., Diehl, E. (2004): Riqueza de formigas (Hymenoptera, Formicidae) epigéicas em povoamentos de Eucalyptus spp. (Myrtaceae) de diferentes idades no Rio Grande do Sul, Brasil. - Revista Brasileira de Entomologia 48(1): 95-100.

[15] Ganho, N.G., Marinoni, R.C. (2006): A variabilidade espacial das famílias de Coleoptera (Insecta) entre fragmentos de Floresta Ombrófita Mista Montana (Bioma Araucária) e plantação de Pinus elliottii Engelmann, no Parque Ecológico Vivat Floresta, Tijuca do Sul, Paraná, Brasil. - Revista Brasileira de Zoologia 23(4): 1159-1167.

[16] Gonçalves-Alvim, S.J., Fernandes, G.W. (2001): Comunidades de insetos galhadores (Insecta) em diferentes fisionomias do Cerrado em Minas Gerais, Brasil. - Revista Brasileira de Zoologia 18(1): 289-305.

[17] Halffter, G., Arellano, L. (2002): Response of dung beetle diversity to human-induced changes in a tropical landscape. - Biotropica 34(1): 144-154.

[18] Hulle, N.L. (2006): Mamíferos de médio e grande porte num remanescente de Cerrado no sudeste do Brasil (Itirapina, SP). Master's Dissertation, Universidade de São Paulo, São Paulo.

[19] Instituto Brasileiro de Meio Ambiente - IBAMA (1997): Instrução Normativa número 109. - Diário Oficial, 12 de Setembro de 1997.

[20] Instituto Brasileiro de Meio Ambiente - IBAMA (2000): Decreto de criação de unidade de conservação s/n de 22 de Setembro de 2000.

[21] Janssen, P., Fortin, D., Hebert, C. (2009): Beetle diversity in a matrix of old-growth boreal forest: influence of habitat heterogeneity at multiple scales. - Ecography 32(3): 423-432.

[22] Lourenço-de-Oliveira, R. (1984): Alguns aspectos da ecologia dos mosquitos (Diptera: Culicidae) de uma área de planície (Granjas Calábria), em Jacarepaguá, Rio de Janeiro. I. Frequência comparativa das espécies em diferentes ambientes e métodos de coleta. Memórias do Instituto Oswaldo Cruz (Rio de Janeiro) 79(4): 479-490.

[23] Loyola, R.D., Martins, R.P. (2008): Habitat structure components are effective predictors of trap-nesting Hymenoptera diversity. - Basic and Applied Ecology 9(6): 765-742.

[24] Marques, G.R.A.M., Forattini, O.P. (2008): Culicídeos em bromélias: diversidade de fauna segundo influência antrópica, litoral de São Paulo. - Revista Saúde Pública 42(6): 979-985. 
[25] McElhinny, C., Gibbons, P., Brack, C. (2006): An objective and quantitative methodology for constructing an index of stand structural complexity. - Forest Ecology and Management 235(1-3): 54-71.

[26] Morato, E.F. (2004): Efeitos da sucessão florestal sobre nidificação de vespas e abelhas solitárias. Doctoral Thesis, Universidade Federal de Minas Gerais, Belo Horizonte.

[27] Neves, F.S., Braga, R.F., Espírito-Santo, M.M., Delabie, J.H.C., Fernandes, G.W., Sánches-Azofeifa, G.A. (2010): Diversity of arboreal ant s in a brazilian tropical dry Forest: Effects of seasonality and successional stage. - Sociobiology 56: 1-19.

[28] Odum, E.P. (1985): Ecologia. - Editora Interamericana, Rio de Janeiro.

[29] Price, P.W., Fernandes, G.W., Waring, G.L. (1987): Adaptative nature of insect galls. Environmental Entomology 16(1): 15-24.

[30] Rafael, J.A., Melo, G.A.R., Carvalho, C.J.B., Casari, A.S., Constantino, R. (2012): Insetos do Brasil: Diversidade e taxonomia. - Editora Holos, Ribeirão Preto.

[31] Ribeiro, J.F., Walter, B.M.T. (1998): Fitofisionomias do bioma Cerrado. - In: Sano, S.M., Almeida, S.P. (ed.) Cerrado: ambiente e flora, Embrapa Cerrados, Brasília.

[32] Root, R.B. (1967): The niche exploitation pattern of the Blue-gray Gnatcatcher. Ecological Monographs 37(4): 317-350.

[33] Romero-Alcaraz, E., Ávila, J.M. (2000): Landscape heterogeneity in relation to variations in epigaeic beetle diversity of a Mediterranean ecosystem. - Implications for conservation. Biodiversity and Conservation 9(7): 985-1005.

[34] Schaffers, A.P., Raemakers, I.P., Sykora, K.V., Braak, C.J.F. (2008): Arthropod assemblages are best predicted by plant species composition. - Ecology 89(3): 782-794.

[35] Silva, R.J., Diniz, S., Vaz-de-Mello, F.Z. (2010): Heterogeneidade do habitat, riqueza e estrutura da assembléia de besouros rola-bostas (Scarabaeidae: Scarabaeinae) em áreas de Cerrado, na Chapada dos Parecis, MT. - Neotropical Entomology 39(6): 934-940.

[36] Silva, N.A.P., Frizzas, M.R., Oliveira, C.M. (2011): Seasonality in insect abundance in the "Cerrado" of Goiás State, Brazil. - Revista Brasileira de Entomologia 55(1): 79-87.

[37] Spies, T.A. (1998): Forest structure - A key to the ecosystem. - Northwest Science 72(2): 34-39.

[38] Tews, J., Brose, U., Grimm, V., Tielbörger, K., Wichmann, M.C., Schwager, M., Jeltsch, F. (2004): Animal species diversity driven by habitat heterogeneity/diversity: the importance of keystone structures. - Journal of Biogeography 31(1): 79-92.

[39] Triplehorn, C.A., Johnson, N.F. (2011): Borror and Delong's introduction to the study of insects. - Editora CENGAGE Learning ${ }^{\mathrm{TM}}$, São Paulo.

[40] Uehara-Prado, M., Bello, A.M., Fernandes, J.O., Santos, A.J., Silva, I.A., Cianciarusi, M.V. (2010): Abundance of epigaeic arthropods in a brazilian savanna under different fire frequencies. - Zoologia 27(5): 718-724.

[41] Vasconcellos, A., Bandeira, A.G., Moura, F.M.S., Araújo, V.F.P., Gusmão, M.A.B., Constantino, R. (2010): Termite assemblages in three habitats under differents disturbance regimes in the semi-arid Caatinga of NE Brazil. - Journal of Arid Environments 74: 298-302.

[42] Vasconcellos, A., Andreazze, R., Almeida, A.M., Araujo, H.F.P., Oliveira, E.S., Oliveira, U. (2010): Seasonality of insects in the semi-arid Caatinga of northeastern Brazil. Revista Brasileira de Entomologia 54(3): 471-476.

[43] Villiers, T.A. (1972): Seed dormancy. - In: Kozlowiski, T.T. (ed.) Seed biology, Academic Press, New York.

[44] Warren, M.W., Zou, X. (2002): Soil macrofauna and litter nutrients in three tropical tree plantations on a disturbed site in Puerto Rico. - Forest Ecology and Management 170(13): $161-171$.

[45] Waquil, J.M. (1997): Amostragem e abundância de cigarrinhas e danos de Dalbulus maidis (DeLong \& Wolcott) (Homoptera: Cicadellidae) em plântulas de milho. - Anais da Sociedade Entomológica do Brasil 26(1): 27-33. 